\title{
Chronic Diarrhoeas in Infancy and Childhood
}

\section{II: Enzyme Content of Duodenal Juice}

\author{
C. J. INGOMAR and E. TERSLEV \\ From the Dronning Louise Children's Hospital and the Department of Clinical Chemistry, \\ Blegdamshospitalet, Copenhagen, Denmark
}

During the period 1960-65 various laboratory tests have been in use when studying children admitted to this hospital with chronic diarrhoea. In a previous paper (Ingomar, Müllertz, and Terslev, 1964) the absorption of D-xylose was reported. The present report concerns pancreatic exocrine function. While this is well known to be often greatly impaired in mucoviscoidosis, less is known about the role of pancreatic disorder in other chronic diarrhoeas of infancy and childhood.

\section{Material and Methods}

The study comprises 112 infants and children. The age distribution at the time of investigation is shown in Table I. This number includes a group of $\mathbf{4 2}$ controls. These had no evidence of malabsorption or maldigestion, after a period of observation in hospital. Included in the control group, however, were a number of children who originally presented with constipation or abdominal colic.

\section{TABLE I}

Age Distribution in Years

\begin{tabular}{|c|c|c|c|c|c|c|c|c|}
\hline Age (yr.) & $<1$ & 1 & 2 & 3 & 4 & 5 & $\geqq 6$ & Total \\
\hline $\begin{array}{l}\text { Controls } \\
\text { Patients }\end{array}$ & $\begin{array}{r}7 \\
14\end{array}$ & $\begin{array}{l}12 \\
10\end{array}$ & $\begin{array}{r}8 \\
10\end{array}$ & $\begin{array}{l}4 \\
5\end{array}$ & $\begin{array}{r}2 \\
12\end{array}$ & $\begin{array}{l}1 \\
6\end{array}$ & $\begin{array}{r}8 \\
13\end{array}$ & $\begin{array}{l}42 \\
70\end{array}$ \\
\hline
\end{tabular}

The group of patients comprises 70 infants and children admitted because of diarrhoea which had given rise to a suspicion of malabsorption or maldigestion. Excluded were cases of diarrhoea due to obvious dietary errors, and cases of intestinal infections or of diarrhoea due to parenteral infections. In $36 \%$ of cases, the duration of the disease exceeded 12 months, in $44 \%$ it was $6-12$ months, and in $20 \%$ less than 6 months. The onset of the disease had been before the age of 1 year in $50 \%$, from 1 to 6 years in $44 \%$, and after 6 years in only $6 \%$.

The enzyme content of the duodenal juice was

Received August 22, 1966. determined by the following methods: amylase (Dahlquist, 1962); lipase (Sarda and Desnuelle, 1958); trypsin (Schwert and Takenaka, 1955), all as modified by Worning and Müllertz (1967).

In the early part of the study fasting duodenal juice was investigated by collecting an arbitrary quantity, sufficient for analysis. Later, it was collected over a period of one hour after oral stimulation by $10 \%$ 'Eledon', * with $2 \%$ rice flour, in a dosage of $300 \mathrm{ml} . / \mathrm{m.}$ body surface area. The position of the duodenal tube was always checked radiologically. The gastric contents were not aspirated. During its collection, duodenal juice was kept refrigerated on ice, and immediately after collection it was frozen to $-16^{\circ} \mathrm{C}$.

The following tests (Ingomar et al., 1964; Ingomar and Terslev, 1966) were also applied to each patient: (1) determination of the fat content of the faeces on a diet with a known fat content, to give the excretion of fat as a percentage of the ingested quantity; (2) D-xylose tolerance test; (3) determination of the sodium and potassium content of the sweat.

On the basis of these three tests the 70 patients were divided into four groups.

Group I (8 cases): sweat test abnormal (sodium excretion $>60 \mathrm{mEq} / \mathrm{l}$. and sodium: potassium ratio $>$ 2.5).

Group II (22 cases): sweat test normal, but D-xylose tolerance test abnormal (maximum xylose concentration in the blood $<26 \mathrm{mg} . / 100 \mathrm{ml}$. following administration of $15 \mathrm{~g}$. D-xylose $/ \mathrm{m}^{2}$ body surface area, and excretion in 24-hour urine $<16 \%$ of the administered quantity).

Group $I I I$ (16 cases): sweat tests and D-xylose tolerance normal, but fat excretion $\geq 10 \%$.

Group IV (24 cases): all three tests normal. (Fat excretion was raised in all cases of Group $I$, and in a number of the Group II cases.)

The classification was based on the expectation that low duodenal enzyme values would be mainly found in Group I which was presumed to be made up of cases of mucoviscoidosis. In Group II we expected to find normal enzyme values, being cases characterized by defective absorption in the small intestine. $\dagger$ In Group

* A Swiss preparation of soured, half-skimmed, dried milk.

t Of the 22 cases of Group II, 10 were finally classified as coeliac disease, and responded to gluten-free diet. 
III the tests used failed to provide an explanation of the steatorrhoea, but if in these cases pancreatic exocrine insufficiency, due not to mucoviscoidosis, but possibly to chronic pancreatitis or to pancreatic hypoplasia, was of importance, low enzyme values might be expected. In Group IV, we might expect to find normal values, assuming that pancreatic exocrine insufficiency is invariably accompanied by steatorrhoea.

\section{Results}

We sought, by a Student t-test, the existence of a significant difference between the mean values for the duodenal enzymes in the control group and in any of the subgroups, paying regard to the difference between the standard deviation in the compared groups (F). Tables II-VII give the $t$-values as well as the probability (p) that the difference between the mean values in the control group and in the patient subgroups was accidental. Since amylase is rapidly destroyed at $p \mathrm{H}<4$, we excluded samples with a $p \mathrm{H}$ lower than 4 in assessing the amylase activity. In assessing the amylase activity in the fasting duodenal juice, moreover, regard was paid to age, as it was significantly lower in children below 6 months $(p=0.01)$. In assessing the lipase activity in the fasting duodenal juice, regard was again paid to age, as it was found to be lower in children under 2 $(\mathrm{p}=0.01)$.

Tables II-VII show that in the fasting duodenal juice, as well as in the duodenal juice after stimulation by a test meal, there were large variations in the quantity of all three enzymes in normal infants and children. As expected, Group I showed significantly low mean values of all three enzymes, by both methods. Group II showed for only one enzyme (amylase in children over 6 months) and only by one of the methods (that of fasting juice) a questionably significant reduction of the mean value.

In Group III the findings were extremely varied. Children of over 6 months showed significantly low amylase activity, but this finding could not be reproduced when using a test meal on a comparable group of infants and children. Similarly, there were significantly low values for lipase in the fasting duodenal juice from children over 2 years of age, but not from those of under 2 years, nor in duodenal juice stimulated by a test meal in infants or children. Trypsin activity was normal by both methods in

TABLE II

Tryptic Activity: Fasting Values (Millienzyme units/l.)

\begin{tabular}{|c|c|c|c|c|c|c|c|c|}
\hline \multirow{2}{*}{ Group } & \multirow{2}{*}{$\frac{\text { Number }}{\mathrm{n}}$} & \multirow{2}{*}{$\frac{\text { Mean }}{M}$} & \multirow{2}{*}{$\begin{array}{c}\begin{array}{c}\text { Standard } \\
\text { Deviation }\end{array} \\
\mathbf{s}\end{array}$} & \multirow{2}{*}{$\frac{\begin{array}{c}\text { Maximal- } \\
\text { Minimal Value }\end{array}}{\text { Max.-Min. }}$} & \multicolumn{2}{|c|}{ Variance Ratio } & \multicolumn{2}{|c|}{$\begin{array}{l}\text { Difference of Mean from } \\
\text { Control Mean }\end{array}$} \\
\hline & & & & & $\mathbf{F}$ & $\mathbf{p}$ & $t$ & $\bar{p}$ \\
\hline Controls & 21 & $4 \cdot 7$ & $3 \cdot 8$ & $12-0 \cdot 6$ & & & & \\
\hline I & 2 & $0 \cdot 2$ & $0 \cdot 1$ & $0 \cdot 4-0$ & 5760 & $\geq 0.01$ & $5 \cdot 3$ & $<0.001$ \\
\hline $\begin{array}{l}\text { II } \\
\text { III }\end{array}$ & $\begin{array}{r}16 \\
7 \\
13\end{array}$ & $\begin{array}{r}10 \cdot 1 \\
6 \cdot 2 \\
6 \cdot 3\end{array}$ & $\begin{array}{l}3 \cdot 7 \\
4 \cdot 8 \\
4 \cdot 1\end{array}$ & $\begin{array}{l}10 \cdot 6-5 \cdot 7 \\
18 \cdot 3-0 \\
13 \cdot 7-0\end{array}$ & $\begin{array}{l}1 \cdot 03 \\
1.6 \\
1 \cdot 2\end{array}$ & $\begin{array}{l}\text { n.s. } \\
\text { n.s. } \\
\text { n.s. }\end{array}$ & $\begin{array}{l}-5 \cdot 1 \\
-0.9 \\
-1 \cdot 3\end{array}$ & $\begin{array}{c}<0.001 \\
\text { n.s. } \\
\text { n.s. }\end{array}$ \\
\hline
\end{tabular}

$\mathrm{F}=$ ratio of variance $\left(\mathrm{s}^{2}\right)$ of each patient group to the variance of the control group, the greater variance being placed as the numerator. $\mathrm{p}=$ probability. n.s. = not significant. $\mathrm{c}=$ control group. $\mathrm{x}=$ any patient group.

$t=\frac{M_{c}-M_{x}}{s \sqrt{\frac{1}{n_{c}}+\frac{1}{n_{x}}}}, S=\sqrt{\frac{S_{c}+S_{x}}{n_{c}+n_{x}-2}}, S_{c}=s_{c}^{2}\left(n_{c}-1\right), S_{x}=s_{x}^{2}\left(n_{x}-1\right)$.

For group $I$, $t$ was calculated as $=\frac{M_{c}-M_{x}}{\sqrt{e_{c}^{2}+e_{x}^{2}}}$, where $e^{2}=\frac{s^{2}}{n}$.

TABLE III

Tryptic Activity: Test Meal Values (Millienzyme units/l.)*

\begin{tabular}{|c|c|c|c|c|c|c|c|c|}
\hline Group & $\mathbf{n}$ & $\mathbf{M}$ & $\mathbf{s}$ & Max.-Min. & $\mathbf{F}$ & p & $\mathbf{t}$ & $\mathbf{p}$ \\
\hline Controls & 16 & $4 \cdot 6$ & $3 \cdot 1$ & $9 \cdot 6-1 \cdot 0$ & & & & \\
\hline$\underset{\text { III }}{\text { II }}$ & $\begin{array}{r}5 \\
6 \\
9 \\
11\end{array}$ & $\begin{array}{l}0 \cdot 3 \\
5 \cdot 1 \\
6 \cdot 2 \\
8 \cdot 5\end{array}$ & $\begin{array}{l}0 \cdot 8 \\
4 \cdot 6 \\
4 \cdot 4 \\
4 \cdot 8\end{array}$ & $\begin{array}{c}1 \cdot 9-0 \\
13 \cdot 9-1 \cdot 4 \\
13 \cdot 9-0 \\
28-2 \cdot 5\end{array}$ & $\begin{array}{r}14 \cdot 2 \\
2 \cdot 2 \\
2 \cdot 0 \\
2 \cdot 4\end{array}$ & $\begin{array}{c}<0.01 \\
\text { n.s. } \\
\text { n.s. } \\
\text { n.s. }\end{array}$ & $\begin{array}{l}5 \cdot 02 \\
-0.5 \\
-1 \cdot 1 \\
-2.5\end{array}$ & $\begin{array}{c}<0.001 \\
\text { n.s. } \\
\text { n.s. } \\
<0.05 \\
>0.01\end{array}$ \\
\hline
\end{tabular}

* For explanation of symbols see Table II. 
TABLE IV

Amylolytic Activity: Fasting Values (Millienzyme units/l.)*

\begin{tabular}{|c|c|c|c|c|c|c|c|c|c|}
\hline Group & Age (yr.) & $\mathbf{n}$ & $\mathbf{M}$ & $\mathbf{s}$ & Max.-Min. & $\mathbf{F}$ & $\mathrm{p}$ & $\mathbf{t}$ & $\mathbf{p}$ \\
\hline Controls & $<\frac{1}{2}$ & 5 & $4 \cdot 6$ & $2 \cdot 7$ & $7 \cdot 5-1$ & & & & \\
\hline $\begin{array}{l}\text { I } \\
\text { II } \\
\text { III }\end{array}$ & 二 & $\begin{array}{l}0 \\
4 \\
2 \\
1\end{array}$ & $\begin{array}{l}54 \cdot 2 \\
13 \cdot 5\end{array}$ & $\begin{array}{l}87 \\
10 \cdot 6\end{array}$ & $\begin{array}{r}185-5 \\
21-6\end{array}$ & $\begin{array}{c}1081 \\
16\end{array}$ & $\begin{array}{l}<0.01 \\
<0.05 \\
>0.01\end{array}$ & $\begin{array}{l}-1 \cdot 1 \\
-1 \cdot 2\end{array}$ & $\begin{array}{l}\text { n.s. } \\
\text { n.s. }\end{array}$ \\
\hline Controls & $>\frac{1}{2}$ & 15 & $221 \cdot 3$ & $189 \cdot 3$ & $815-26 \cdot 3$ & & & & \\
\hline I & - & 2 & $3 \cdot 5$ & $3 \cdot 5$ & 6-1 & & $\begin{array}{l}<0.05 \\
>0.01\end{array}$ & & $<0.001$ \\
\hline II & - & 12 & 108 & $41 \cdot 4$ & $165-35$ & 20 & $<0.01$ & $2 \cdot 2$ & $\begin{array}{l}<0.05 \\
>0.01\end{array}$ \\
\hline III & 一 & 5 & $23 \cdot 6$ & $25 \cdot 9$ & $59-0$ & $53 \cdot 2$ & $<0.01$ & $3 \cdot 7$ & $<0.01$ \\
\hline IV & - & 13 & 173 & 116 & $444-57$ & $2 \cdot 6$ & $\begin{array}{l}<0.05 \\
>0.01\end{array}$ & $0 \cdot 8$ & n.s. \\
\hline
\end{tabular}

* For explanation of symbols see Table II.

TABLE V

Amylolytic Activity: Test Meal Values (Millienzyme units/l.)*

\begin{tabular}{|c|c|c|c|c|c|c|c|c|}
\hline Group & $\mathbf{n}$ & $\mathbf{M}$ & $\mathbf{s}$ & Max.-Min. & $\mathbf{F}$ & p & $\mathbf{t}$ & p \\
\hline Controls & 18 & 61 & 24 & $105-24$ & & & & \\
\hline $\begin{array}{l}\text { I } \\
\text { II } \\
\text { IIV }\end{array}$ & $\begin{array}{r}6 \\
5 \\
10 \\
9\end{array}$ & $\begin{array}{l}18 \cdot 1 \\
58 \cdot 4 \\
84 \cdot 3 \\
99 \cdot 8\end{array}$ & $\begin{array}{l}15 \cdot 7 \\
31 \cdot 8 \\
96 \cdot 0 \\
77 \cdot 0\end{array}$ & $\begin{array}{l}28-0 \cdot 35 \\
100-14 \cdot 3 \\
243-0 \\
222-14\end{array}$ & $\begin{array}{c}2 \cdot 33 \\
1 \cdot 77 \\
16 \\
10 \cdot 4\end{array}$ & $\begin{array}{l}\text { n.s. } \\
\text { n.s. } \\
<0.01 \\
<0.01\end{array}$ & $\begin{array}{r}4.4 \\
0.2 \\
-0.8 \\
-1.5\end{array}$ & $\begin{array}{l}<0.001 \\
\text { n.s. } \\
\text { n.s. } \\
\text { n.s. }\end{array}$ \\
\hline
\end{tabular}

* For explanation of symbols see Table II.

TABLE VI

Lipolytic Activity: Fasting Values (Millienzyme units/l.)*

\begin{tabular}{|c|c|c|c|c|c|c|c|c|c|}
\hline Group & Age (yr.) & $\mathrm{n}$ & $\mathbf{M}$ & s & Max.-Min. & $\mathbf{F}$ & $\mathrm{p}$ & $t$ & $\mathbf{p}$ \\
\hline Controls & $<2$ & 8 & 94 & 55 & $200-24$ & & & & \\
\hline $\begin{array}{c}\text { I } \\
\text { II } \\
\text { III }\end{array}$ & E & $\begin{array}{r}0 \\
11 \\
4 \\
2\end{array}$ & $\begin{array}{l}177 \\
111 \\
272\end{array}$ & $\begin{array}{r}121 \\
68 \\
49\end{array}$ & $\begin{array}{l}471-48 \\
190-29 \\
307-237\end{array}$ & $\begin{array}{l}2 \cdot 21 \\
1 \cdot 55 \\
1 \cdot 23\end{array}$ & $\begin{array}{l}\text { n.s. } \\
\text { n.s. } \\
\text { n.s. }\end{array}$ & $\begin{array}{l}-0.66 \\
-0.4 \\
-4.7\end{array}$ & $\begin{array}{l}\text { n.s. } \\
\text { n.s. } \\
<0.01 \\
>0.001\end{array}$ \\
\hline Controls & $>2$ & 14 & 209 & 86 & $390-77$ & & & & \\
\hline$\underset{\text { III }}{\text { II }}$ & E & $\begin{array}{l}2 \\
5 \\
2\end{array}$ & $\begin{array}{r}0 \\
207 \\
1\end{array}$ & $\begin{array}{c}0 \\
122 \\
1 \cdot 4\end{array}$ & $\begin{array}{c}0-0 \\
321-12 \\
2-0\end{array}$ & $\begin{array}{l}2 \cdot 01 \\
5282\end{array}$ & $\begin{array}{l}\text { n.s. } \\
<0.05 \\
>0.01\end{array}$ & $\begin{array}{l}8 \cdot 7 \\
0 \cdot 01 \\
9 \cdot 0\end{array}$ & $\begin{array}{l}<0.001 \\
\text { n.s. } \\
<0.001\end{array}$ \\
\hline IV & - & 12 & 198 & 120 & $353-35$ & $1 \cdot 95$ & n.s. & $0 \cdot 3$ & n.s. \\
\hline
\end{tabular}

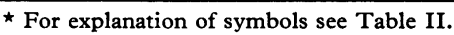

TABLE VII

Lipolytic Activity: Test Meal Values (Millienzyme units/l.)*

\begin{tabular}{|c|c|c|c|c|c|c|c|c|}
\hline Group & $\mathrm{n}$ & $\mathbf{M}$ & $\mathbf{s}$ & Max.-Min. & F & p & $\mathbf{t}$ & $\mathbf{p}$ \\
\hline Controls & 17 & 104 & 118 & $280-6$ & & & & \\
\hline I & 6 & 4 & $6 \cdot 5$ & $17-0$ & 331 & $<0.01$ & $3 \cdot 49$ & $<0.01$ \\
\hline $\begin{array}{l}\text { II } \\
\text { III }\end{array}$ & $\begin{array}{r}6 \\
9 \\
11\end{array}$ & $\begin{array}{l}159 \\
179 \\
277\end{array}$ & $\begin{array}{r}82 \\
134 \\
203\end{array}$ & $\begin{array}{l}238-32 \\
388-0 \\
668-101\end{array}$ & $\begin{array}{l}2 \cdot 1 \\
1 \cdot 3 \\
2 \cdot 9\end{array}$ & $\begin{array}{l}\text { n.s. } \\
\text { n.s. } \\
\text { n.s. }\end{array}$ & $\begin{array}{l}-0.3 \\
-1 \cdot 6 \\
-2.9\end{array}$ & $\begin{array}{l}\text { n.s. } \\
\text { n.s. } \\
<0.01 \\
>0.001\end{array}$ \\
\hline
\end{tabular}

\footnotetext{
* For explanation of symbols see Table II.
} 
this group. It was concluded that Group III was a heterogeneous one, in which reduced pancreatic function was not of the same importance as in Group I. Nevertheless, there were in Group III 2 cases showing an activity of all three enzymes within the low range characteristic of Group I. In one of these cases, concomitant hepatic disease made it difficult to evaluate the significance of the low enzyme values. The other case, on exploratory laparotomy, showed a chronic pancreatitis with total atrophy of the pancreas (Ingomar and Terslev, 1965).

In Group IV, there was no case with a significantly low enzyme activity.

\section{Discussion}

The varying enzyme activity found here in normal fasting duodenal juice corresponds, in respect to amylase and trypsin, to the findings of others (Neale and Klumpp, 1930; Andersen, 1942; Farber, Shwachman, and Maddock, 1943; Jones, 1956). The significantly lower lipase activity in the fasting juice from infants and children under 2 years of age, as compared with children over 2 years, has also been noted previously by Neale and Klumpp (1930), though this difference has been questioned by others (Andersen, 1942; Farber et al., 1943; Véghelyi, 1949; Jones, 1956). Others who have used stimulation have employed either high-fat test meals (Myers, Free, and Beams, 1938; Shwachman and Leubner, 1955) or secretin (Maddock, Farber, and Shwachman, 1943; Gibbs, 1950), so that their results cannot be compared with ones using a lowfat test meal.

Thus, by neither of the two methods is it possible to set up a normal range, though values coinciding with those of Group I must be judged as low. In infants under 6 months, however, the amylase activity in the fasting duodenal juice is normally so low that at this age this enzyme should not form the basis of any assessment of pancreatic function.

Other workers have found a low amylase activity in the fasting duodenal juice from infants and children with chronic diarrhoeas, due to parenteral infections, and with a normal excretion of fat (Andersen, 1942), and in infants and children with 'idiopathic coeliac disease' (Jones, 1956). A low lipase activity in the fasting duodenal juice from infants and children with 'chronic nutritional disturbances', due to parenteral infection, was reported by Farber et al. (1943). Our investigations do not support these findings, but as the patients of these series do not appear to have had the sweat test or D-xylose test, the cases are not directly comparable. Finally, we found no case of partial pancre- atic exocrine insufficiency in mucoviscoidosis (Gibbs, Bostick, and Smith, 1950), and no cases of isolated trypsin deficiency (Townes, 1965), or congenital lipase deficiency (Sheldon, 1964).

\section{Summary}

In 42 normal infants and children and in 70 infants and children with chronic diarrhoeas, the amylase, lipase, and trypsin content of the duodenal juice was studied during fasting or following oral stimulation by a test meal. Both methods revealed such marked variations in the quantity of all three enzymes that it is impossible to define a normal range. Neither of the two methods proved superior.

As in previous studies, the amylase activity in the fasting duodenal juice from infants under 6 months of age was low, and lipase activity was lower in infants and children under 2 years of age than from children over 2 years.

A consistently low enzyme activity was found only in patients with mucoviscoidosis, while infants and children with a normal sweat test, normal fat excretion, and normal D-xylose tolerance test had enzyme values no lower than a control group. Infants and children having normal sweat tests but abnormally low D-xylose tolerance tests failed to show evidence of any reduced pancreatic exocrine function.

A group of infants and children with normal sweat tests and normal D-xylose tolerance tests, but an increased excretion of fat, showed moderately low values for some of the enzymes, suggesting that in such cases pancreatic exocrine insufficiency may be of significance. Study of the duodenal juice is particularly indicated for this category of child with chronic diarrhoea.

\section{REFERENCES}

Andersen, D. H. (1942). Pancreatic enzymes in the duodenal juice in the celiac syndrome. Amer. $\mathcal{F}$. Dis. Child., 63, 643.

Dahlquist, A. (1962). A method for the determination of amylase in the intestinal content. Scand. F. clin. Lab. Invest., 14, 145.

Farber, S., Shwachman, H., and Maddock, C. L. (1943). Pancreatic function and disease in early life. I. Pancreatic enzyme activity and the celiac syndrome. $\mathcal{f}$. clin. Invest., 22, 827.

Gibbs, G. E. (1950). Secretin tests with bilumen gastroduodenal drainage in infants and children. Pediatrics, 5, 941.

, Bostick, W. L., and Smith, P. M. (1950). Incomplete pancreatic deficiency in cystic fibrosis of the pancreas. $\mathcal{F}$. Pediat., 37, 320.

Ingomar, C. J., Müllertz, S., and Terslev, E. (1964). Chronic diarrhoeas in infancy and childhood. I: D-xylose tolerance test. Arch. Dis. Childh., 39, 79.

- and Terslev, E. (1965). A case of chronic pancreatitis in early childhood. Dan. med. Bull., 12, 91.

, and - (1966). Chronic diarrhoeas in infancy and childhood. Laboratory and radiological findings. Pediatrics Digest, 8, 41.

Jones, J. A. (1956). Studies on pancreatic enzymes. A comparison of fasting duodenal juice before and after gastric aspiration. F. Pediat., 49, 672. 
Maddock, C. L., Farber, S., and Shwachman, H. (1943). Pancreatic function and disease in early life. II. The effect of secretin on pancreatic function of infants and children. Amer.F. Dis. Child., 66, 370.

Myers, V. C., Free, A. H., and Beams, A. J. (1938). Variations in the enzymatic activity of duodenal contents. Amer. F. dig. Dis., $5,464$.

Neale, A. V., and Klumpp, T. G. (1930). The gastric and duodenal contents of normal infants and children. Amer. F. Dis. Child. 40, 1215.

Sarda, L., and Desnuelle, P. (1958). Action de la lipase pancréatique sur les esters en émulsion. Biochim. biophys. Acta (Amst.), 30, 513.
Schwert, G. W., and Takenaka, Y. (1955). A spectrophotometric determination of trypsin and chymotrypsin. ibid., 16, 570 .

Sheldon, W. (1964). Congenital pancreatic lipase deficiency. Arch. Dis. Childh., 39, 268.

Shwachman, H., and Leubner, H. (1955). Mucoviscidosis. Advanc. Pediat., 7, 249.

Townes, P. L. (1965). Trypsinogen deficiency disease. F. Pediat., 66, 275.

Véghelyi, P. V. (1949). Pancreatic enzymes: Normal output and comparison of different methods of assay. Pediatrics, 3, 749.

Worning, H., and Müllertz, S. (1967). $p \mathrm{H}$ and pancreatic enzymes in the human duodenum during digestion of standard meal. Scand. $\mathcal{F}$. Gastroenterology. In the press. 